\title{
Challenges of cross-cultural communications in the era of the COVID-19 pandemic
}

\author{
Anna Alekseevna Aksenova*, Ekaterina Yurievna Andreeva, Anastasiya Andreevna \\ Lugovaya, and Nataliya Yurievna Tikhonova \\ Financial University under the Government of the Russian Federation, Department of Foreign \\ Languages and Cross-Cultural Communication, Moscow, Russia
}

\begin{abstract}
This article examines questions of the present interest in the sphere of modern education, the key topic of which is cross-cultural online communication of students in the context of the COVID-19 pandemic and complete shift to the distant format of work. The article analyzes the features of virtual communication between representatives of different cultures and languages, as well as examples of possible misunderstandings of certain cultural realities. The issue of effective communication and socialization of students in the online environment is debatable and relevant to study, which is proved by numerous studies derived from real interactions with foreign students during the period of necessary self-isolation due to the threat of coronavirus. The investigation is based on a questionnaire suggested to students and Internet discourse materials presented on websites and forums. The theoretical basis is a deep analysis of the articles of scientists who decided to delve into the linguistic aspect dictated by the need to study the phenomenon of communication during the pandemic. The task of this research is to analyze cases and Internet communication based on the conducted survey and data comparison. The article will provide views on the mentioned above matter supported by investigations of respected scientists with various illustrations from modern realities of the pandemic world.
\end{abstract}

Keywords: cross-cultural communication, cultural misconceptions, online learning, COVID-19 pandemic, socialization

\section{Introduction}

In view of recent events, a key issue influencing modern reality is the COVID-19 pandemic. The epidemic captured the minds of the world community. All spheres of life were completely subordinated to the pandemic. For universities, this period was "full of uncertainties" [1]. According to many observers, this area has undergone various challenges introducing the latest technologies [2]. Due to the epidemiological situation and virus infection hazard, educational institutions had to switch to online distance learning. All participants in the educational process faced inevitable challenges, one of which turned out

*Corresponding author: AAAksenova@fa.ru 
to be cross-cultural communication. There is also a risk of losing international networks [3]. That is why the problem of "cultural awareness" [4] has become one of the key aspects of students' intercultural online communication and one of the key points of investigation for researchers. Some Russian scholars analyzed the subject of socio-cultural phenomena and examined changes that the language and the aspect of intercultural communication have undergone [5]. Other scholars dwell upon the shift in the educational sphere caused by the pandemic crisis and various socio-cultural consequences [6].

In the analyzed cases, there are illustrations of the difficulties that foreign students faced when solving language and cultural problems. It is claimed that all communication misunderstandings were solved through communication and by asking questions. The study aims to analyze all problems and difficult situations during online and offline communication between international students.

\section{$2 \quad$ Methods}

The study examines the communication challenges faced by students during the lockdown in 2020-2021 and the ways of overcoming them. Two research methods were combined for the purpose of the study. The first is a discourse analysis of written online communication. The most confusing communicative situations were selected by means of continuous sampling, and then the vocabulary level and cultural patterns were examined.

Second, the convenience sampling method was used to analyze communicative problems. Two questionnaires were used in the survey: for Fulbright alumni and future Fulbright students. The questionnaire for Fulbright alumni included 12 open-ended questions. The other questionnaire with 7 open-ended questions was created for Russian students who obtained a Fulbright scholarship in 2020-2021. This method enabled the quick gathering of the data and its convenient comparison.

\section{Results}

\subsection{Misunderstanding between students in social media}

Cultural differences between international students are clearly visible in the correspondence on various popular educational Internet platforms. To illustrate different attitudes of students towards some cultural phenomena, the authors analyzed chats on Coursera.Community, a platform offering discussions on various topics connected with on-demand courses.

Non-verbal communication is considered to be one of the most important areas to study cultural incongruities. The main components of non-verbal communication can be a dress code, posture, gestures, facial expressions, and surrounding objects [7, 8]. In writing, in modern electronic communications, these means are expressed by emoji, which vary from country to country "due to linguistic differences in expressing emotions and diversity in conceptualizing topics" [9]. In one of the chats on Coursera.Community, one of the students uses the emoji called "a ring gesture" (performed by connecting the thumb and index into a circle) which is regarded as a manifestation of rudeness ("You use obscene gestures!") by another student, while the person just wanted to say "It's ok!". Although this sign looks quite harmless in Russia or the USA, in Brazil, Greece, Spain, and several Middle Eastern countries it can be seen as obscene. So, the student who used this controversial emoji had to apologize explaining that he had not had any intention to offend anybody. 


\subsection{Cultural gaps caused by specific realia: challenges and solutions}

The process of informal online communication between students is also characterized by misunderstandings frequently arising due to the lack of correspondence between realia pertaining to different cultural contexts [10]. These realia sometimes have a direct relation to the concepts of education. Such academic realia either do not exist in other cultures or have some rough equivalents [11]. Multiple examples can be found while analyzing Reddit, a website that is basically a network of interest-oriented user-generated communities.

One of such Reddit discussions, which are called threads, includes students' funny stories about their university professors. Some of these stories, perhaps the funniest ones, feature professors described by the word tenured. Students who are not from European countries or the United States do not understand this term because their educational systems lack this phenomenon altogether, therefore, they do not get the joke. To illustrate this point, the following parts of the threads can be provided [12]:

One of the chairs of our department is from Nigeria and I swear he has the best stories. He's tenured and a department chair so his classes are pretty much "You listen to my stories and laugh, you get an $A$ " < ... $>$

Once my ancient philosophy professor made a huge mistake in explaining some logical proposition, and stared at the board in silence. After a minute, he said, "Thank God for tenure."

The next extract gives a proper understanding of what this term actually means:

Well it's a letter informing me I now have tenure which means it's damn near impossible for them to fire me.

The definition can be broadened: when a professor has gained tenure, he or she can only be terminated for a justifiable cause or under extreme circumstances, such as program discontinuation or severe financial restraints. Now it is clear why tenured professors no longer worry about their future careers. The examples with the word tenure represent the case when European and American realia are not found in many other cultures at all.

The next parts of the discussions will exemplify a situation when realia exist not only in the USA but in other places as well, however, they are structured differently so their names will vary from country to country. This is the case with the names of university subjects, for instance, Pre-Calc, Calc 1, and Calc 2 [13]:

I had a Pre-Calc teacher that would become absorbed in his work on the board $<\ldots>$

Haven't had one that strange [professor]. But my Calc 1 professor said he was always a cat guy but saw no reason to mourn their deaths. $<\ldots>$

My calc 2 professor told us that she was going to teach us how to "take advantage of the series in a dirty, shameful way"... she was an odd one.

It is obvious that all these subjects relate to mathematics (there are words with the same root: calculate, calculation, calculator) though the subtle difference is difficult to identify without referring questioners to the particular mathematics curriculum.

\subsection{Challenges in real-life communication faced by Russian Fulbright students}

Eleven Russian students participated in the survey for Fulbright alumni. They lived and studied in the USA in the period of 2010-2021, from 9 months to 5 years. The table below represents the data of the survey. 
Table 1. Communication problems of Russian students, Fulbright alumni.

\begin{tabular}{|c|c|}
\hline Question & Answer \\
\hline $\begin{array}{l}\text { Did you study the American culture, language, } \\
\text { and lifestyle before coming to the U.S.? Which } \\
\text { sources did you research? }\end{array}$ & $\begin{array}{l}55 \% \text {-yes; } \\
45 \% \text { - no; } \\
\text { Sources: Internet, Facebook, podcasts, TV, } \\
\text { books, friends and relatives from the USA }\end{array}$ \\
\hline $\begin{array}{l}\text { Which difficulties did you experience } \\
\text { communicating with your new American friends } \\
\text { in the USA? }\end{array}$ & $\begin{array}{l}9 \% \text { - experienced no difficulties; } \\
9 \% \text { - no answer; } \\
27 \% \text { - communication difficulties based on } \\
\text { language issues: vocabulary, accent, speed of } \\
\text { speech; } \\
55 \% \text { - communication difficulties based on } \\
\text { cultural differences }\end{array}$ \\
\hline $\begin{array}{l}\text { Do you think your mother tongue and } \\
\text { play a negative role? If yes, how? }\end{array}$ & $\begin{array}{l}82 \%-\text { no; } \\
18 \% \text {-yes }\end{array}$ \\
\hline $\begin{array}{l}\text { Which reasons make it hard to understand } \\
\text { American people? }\end{array}$ & $\begin{array}{l}18 \% \text { - had no problems with understanding; } \\
36 \%-\text { understanding difficulties based on } \\
\text { language issues; } \\
46 \%-\text { understanding difficulties based on } \\
\text { cultural differences }\end{array}$ \\
\hline
\end{tabular}

Ten people participated in the survey for future Fulbright students. The table below represents the data of the survey.

Table 2. Communication problems of Russian students, Fulbright students of 2020-2021.

\begin{tabular}{|c|c|}
\hline Question & Answer \\
\hline $\begin{array}{l}\text { Do you study the American culture, language, } \\
\text { and lifestyle before coming to the U.S.? Which } \\
\text { sources do you research? }\end{array}$ & $\begin{array}{l}10 \%-\text { no; } \\
90 \% \text { - yes; } \\
\text { Sources: books, textbooks, Internet, YouTube, } \\
\text { friends, series, TED-talks }\end{array}$ \\
\hline $\begin{array}{l}\text { Which communication problems do you expect } \\
\text { to experience with your new American friends in } \\
\text { the USA? }\end{array}$ & $\begin{array}{l}20 \%-\text { do not expect any problems; } \\
30 \%-\text { communication difficulties based on } \\
\text { language issues: vocabulary, slang; } \\
40 \%-\text { communication difficulties based on } \\
\text { cultural differences }\end{array}$ \\
\hline $\begin{array}{l}\text { Do you think your mother tongue and culture } \\
\text { may cause difficulties? If yes, how? }\end{array}$ & $\begin{array}{l}30 \%-\text { yes; } \\
\text { Reasons: politics, cultural peculiarities; } \\
20 \% \text { - no; } \\
50 \% \text { - no answer }\end{array}$ \\
\hline $\begin{array}{l}\text { Which reasons can hinder the understanding of } \\
\text { American people? }\end{array}$ & $\begin{array}{l}70 \%-\text { understanding difficulties based on } \\
\text { language issues; } \\
30 \% \text { - understanding difficulties based on } \\
\text { cultural differences }\end{array}$ \\
\hline
\end{tabular}

\section{Discussion}

Misunderstandings typical of online communication can be caused by cultural gaps occurring as a result of the existence of non-matching academic realia across different cultures. Bridging such gaps is possible if foreign students do their research when it comes to new words as well as familiar words in new contexts. Cultural peculiarities connected with the traditional perception of extralinguistic parts of written communication (emoji) can also cause misunderstanding. However, active participation in "co-curricular cross-cultural experiences" has a positive impact on one's integration into the global context [14]. The 
best way to help anticipate culture shock is to engage in online chats with foreign students who are well aware of the subtleties of university activities [15].

According to the survey results, Fulbright alumni researched about American culture and language less than future Fulbright students do. At the same time, the sources of information are different: future Fulbright students tend to use various sources of information including both Netflix series and scientific articles on culture shock. However, Fulbright alumni indicate various reasons for misunderstanding, including rules of politeness, mentality, and psychological differences between Russians and Americans.

The cases presented in the article show that communication problems can be based both on language difficulties and cultural peculiarities unfamiliar to international students. The results of the survey in turn support this idea, since both the alumni and future students single out these two types of difficulties. It is also noticeable that blended learning was not mentioned as a possible learning challenge. Seventy-seven percent of the respondents assume that communication problems can be solved only by means of communication: asking for more details, explaining one's ideas, and establishing friendly relations. It confirms the ideas by other scholars that one important way to learn a new culture is "through communication and interaction" [16] and the higher level of cultural competence could be a manifestation of one's experience [17].

\section{Conclusion}

To sum up, it can be observed that the issue of cultural mismatches among international students has become quite urgent nowadays. With the development of various internship programs, educational online platforms, and student conferences, cultural differences between representatives of different nationalities come into light more and more often. Therefore, before moving to another country, it is essential for a student to learn more about its culture and traditions to avoid misunderstanding and awkward situations both in verbal and non-verbal spheres of communication and be ready to solve communication difficulties using the means of communication.

\section{References}

1. S. Potra, A. Pugna, R. Negrea, Int J Environ Res Pub Health, 18, 1-15 (2021). https://doi.org/10.3390/ijerph18063058

2. I.I. Klimova, et al., XLinguae, 11, 67-74 (2018). https://doi.org/10.18355/XL.2018.11.01XL.07

3. A. Hobday, et al., Oceanography, 33(4), 9-10 (2020). https://doi.org/10.5670/oceanog.2020.414

4. I. Klimova, G. Klimova, S. Dubinka, XLinguae, 12, 207-218 (2019). https://doi.org/10.18355/XL.2019.12.01.16

5. I.I. Klimova, N.A. Kozlovtseva, M.E. Konurbaev, Human. Fin Univ Bul, 11(2), 41-46 (2021). https://doi.org/10.26794 / 2226-7867-2021-11-2-41-46

6. P. Stanistreet, M. Elfert, D. Atchoarena, Int Rev Edu, 66(5), 627-633 (2021). https://doi.org/10.1007/S11159-020-09880-9

7. V.I. Medvedeva, Iskusstvo i nauka obshcheniya: neverbalnaya kommunikatsiya [The art and science of communication: non-verbal communication] (Institute of Psychology RAS, Moscow, 1998) 
8. M.C. Uyanne, O.J. Oti, Int J Arts Human, 1(4), 98-111 (2012)

9. S.Ch. Guntuku, et al., Studying Cultural Differences in Emoji Usage across the East and West, in Proceedings of the Thirteenth International AAAI Conference on Web and Social Media (ICWSM), 13(01), 226-235 (2019)

10. L.A. Arasaratnam, M.L. Doerfel, Int J Intercult Rel, 29, 137-163 (2005). https://doi.org/10.1016/j.ijintrel.2004.04.001

11. S.G. Ter-Minasova, Yazyk i mezhkulturnaya kommunikatsiya [Language and intercultural communication] (Slovo, Moscow, 2000)

12. What's the funniest thing a professor has ever said in front of your class? Accessed on: October 11, 2021. [Online]. Available:

https://www.reddit.com/r/AskReddit/comments/dp81t/whats_the_funniest_thing_a_prof essor_has_ever/

13. Strangest professor you've ever had? Accessed on: October 11, 2021. [Online]. Available:

https://www.reddit.com/r/EngineeringStudents/comments/bvcen0/strangest_professor_ youve_ever_had/

14. C.M. Poole, B.R. William, J Edu, 195(3), 41-52 (2015). https://doi.org/10.1177/002205741519500305

15. H. Spencer-Oatey, P. Franklin, Intercultural Interaction. A Multidisciplinary Approach to Intercultural Communication (Chippenham and Eastbourne, 2009).

https://doi.org/10.1093/applin/amq019

16. I. Wang, et al., J Int Students, 7(3), 555-582 (2017). https://doi.org/10.5281/zenodo.570023

17. S.A. Buddington, A.M. Esmail, Race, Gender Class, 24(1-2), 160-171 (2017) 